\title{
20 ANSWERS: RECONCILING AIR TRAVEL AND CLIMATE CHANGE
}

\section{Ralf Buckley \\ Griffith University, Australia}

Climate change has become a very significant issue for the global tourism industry, as reviewed recently by Buckley (2010), and Weaver (2011, in press). It may affect the perceived attractiveness of different tourism destinations relative to each other and to countries of origin (Buckley, 2008; Eugenio-Martin \& Campos-Soria, 2010; Hares, Dickinson, \& Wilkes, 2010). It may affect air travel through mitigation and offset measures (Buckley, 2010; Mair 2011; Scott, Peeters, \& Gössling, 2010). It may affect travel patterns through increased financial and social costs (Hares et al., 2010).

Most people in developed nations are aware of attempts to reduce greenhouse gas emissions, including those from air travel, by mechanisms including emission taxes and offset programs (Bristow, Wardman, Zanni, \& Chintakayala, 2010; Miller, Rathouse, Scarles, Holmes, \& Tribe, 2010). Even so, they continue to travel on vacation to distant destinations, even those at particular risk from climate change (Dawson, Stewart, Lemelin, \& Scott, 2010; Eijgelaar, Thaper, \& Peeters, 2010); and tourism industry associations and destination marketing organisations lobby them to do so.

Individual travellers thus receive conflicting external signals. This contribution examines how they rationalise their decisions. It focuses on longhaul air travel from developed to developing nations, the largest tourism contributor to climate change. It also focuses on two groups with highest knowledge and awareness of tourism's climate impacts: clients of commercial ecolodges, and university students taking international ecotourism field courses. The groups overlapped in age, wealth, and education. Gender balance was even in both groups. The members of both groups originated in developed nations around the world.

Their views were elicited through individual semi-structured interviews, conducted after several days of general conversation to establish rapport. Discussions were recorded as notes and quotes shortly after each interview. Some were continued via email and Facebook ${ }^{\circledR}$. All interviews took place in public areas and informal settings. No incentives or inducements were offered. Arguments both for and against longhaul travel to developing countries were canvassed, so that participants had unpressured opportunities to express any relevant viewpoint. Fifty interviews were held. No new responses were received after the first 30 . 
The data generated represent over 100 hours of individual interview content. This compares, for example, to 8 groups of about 8 people each in joint focus-group discussions for Miller et al. (2010). Responses were dissected into small-scale conceptual components which were classified and reassembled iteratively, following standard procedure for qualitative analysis of interview materials (Rubin \& Rubin, 2005). A total of 87 items were extracted, falling into 28 categories with 1-6 respondents mentioning each, though in different words. The breadth of responses is notable: 7 categories were mentioned by $5-6$ respondents, 9 by $3-4$ and 12 by $1-2$.

Results are summarised in Table 1. Fewer than one third of respondents expected to change their travel patterns so as to reduce climate change impacts. Over two thirds planned to continue travelling as currently. Those who plan to travel less or save money focus on mechanisms, rationales and constraints. Those who plan to keep travelling provide a wide range of justifications. Similar though less varied results were reported by Stoll-Kleemann, O’Riordan, and Jaeger (2001) for climate change mitigation measures more broadly.

Most of these justifications would be considered socially and morally acceptable by peers of those travelling. Visiting relatives or spending holidays with partner or children are considered as social obligations; and the wealthy accept each others' fortunes. Only the arguments of childlessness, planetary doom and retrospective intergenerational equity are potentially contentious.

These results suggest that even environmentally knowledgeable people will reallocate funds and rationalise continued holiday travel, even under greatly increased airfares. This matches the results of econometric approaches (Tol, 2007) for carbon taxes up to $>50$ those proposed and $>100 \cdot$ current offset costs. Carbon taxes would thus raise revenue but would not reduce air travel or emissions. This applies for many environmental taxes (Buckley, 1991).

If air travel costs and social contexts change gradually, then quantitative survey techniques and econometric models can provide more precise estimates of how people are likely to change their behaviours, lifestyles, mobilities and expenditures. For such approaches to be reliable, however, they must include all likely categories of change. This contribution shows that there are many more categories than considered previously. Rationalisations relying on social obligations, in particular, merit further research attention.

Ralf Buckley: International Centre for Ecotourism Research Griffith University, Gold Coast, Qld 9726, Australia. Tel.: +61 7 55528675; fax:+61 7 55528895. Email <r.buckley@griffith.edu.au>. 


\section{REFERENCES}

Bristow, A., Wardman, M., Zanni, A., \& Chintakayala, P. (2010). Public acceptability of personal carbon trading and carbon tax. Ecological Economics, 69, 1824-1837.

Buckley, R. (1991). Green taxes: Legal and policy issues in using economic instruments for environmental management. Revenue Law Journal, 2, 27-41.

Buckley, R. (2008). Climate change: Tourism destination dynamics. Tourism Recreation Research, 33, 354-355.

Buckley, R. (2010). Tourism under climate change: Will slow travel supersede short breaks? Ambio doi: 10.1007/s13280-010-0100-x, in press.

Dawson, J., Stewart, E., Lemelin, H., \& Scott, D. (2010). The carbon cost of polar bear viewing tourism in Churchill, Canada. Journal of Sustainable Tourism, 18, 319-336.

Eijgelaar, E., Thaper, C., \& Peeters, P. (2010). Antarctic cruise tourism: The paradoxes of ambassadorship, "last chance tourism”' and greenhouse gas emissions. Journal of Sustainable Tourism, 18, 337-354.

Eugenio-Martin, J., \& Campos-Soria, J. (2010). Climate in the region of origin and destination choice in outbound tourism demand. Tourism Management, 31, 744-753.

Hares, A., Dickinson, J., \& Wilkes, K. (2010). Climate change and the air travel decisions of UK tourists. Journal of Transport Geography, 18, 466-473.

Mair, J. (2011). Exploring air travellers' voluntary carbon-offsetting behaviours. Journal of Sustainable Tourism, 19, 215-230.

Miller, G., Rathouse, K., Scarles, C., Holmes, K., \& Tribe, J. (2010). Public understanding of sustainable tourism. Annals of Tourism Research, 37, 627-645. 
Rubin, J. R., \& Rubin, I. S. (2005). Qualitative interviewing: the art of hearing data (2nd ed.). Sage: Thousand Oaks.

Scott, D., Peeters, P., \& Go“ssling, S. (2010). Can tourism deliver its “aspirational” greenhouse gas emission reduction targets. Journal of Sustainable Tourism, 18, 393-408.

Stoll-Kleemann, S., O’Riordan, T., \& Jaeger, C. (2001). The psychology of denial concerning climate mitigation measures: Evidence from Swiss focus groups. Global Environmental Change, 11, 107-117.

Tol, R. (2007). The impact of a carbon tax on international tourism. Transportation Research Part D, 12, 129-142.

Weaver, D. (2011). Can sustainable tourism survive climate change?. Journal of Sustainable Tourism, 19, 5-15 
Table 1. Reconciling Air Travel and Climate Change Impacts at Individual Scale

\section{Categories}

\section{Typical phrase}

\section{REDUCE IMPACTS (30\%)}

Travel less in total

1. travel less frequently(10\%)

fewer trips

2. travel less far(10\%) consistency between home and holiday lifestyles(6\%) doubt reliability of airline carbon offset programs(4\%)

3. substitute other types of expenditure for holiday travel(4\%) close to home energy saving if they work shopping instead

Travel to fewer destinations

4. learn more about destinations visited(4\%)

5. travel overland from single gateway airport(2\%)

6. stay longer at individual destinations(6\%)

constraints on longer stays time away from other commitments(6\%) desire to travel with friends(6\%)

appreciate things overland journey spend more time

finding time travel together

\section{SAME IMPACTS (70\%)}

Save money and keep travelling

7. put more effort into planning holiday travel(6\%)

8. search for discounted fares( $2 \%)$

9. select destinations which are cheaper to get to(8\%)

10. cheaper accommodation and activities at destinations(4\%)

11. change home lifestyle so as to afford travel(10\%)

plan carefully specials, standbys cheaper places keep it cheap save harder

Pay more and keep travelling

12. buy carbon offsets( $2 \%)$

13. having no children offsets individual impacts(2\%)

buy offsets

less impact

14. obligations to visit relatives(14\%)

family thing

can't say no

15 . worthy gift to children(12\%)

give to my kids

16. special occasions with partner(12\%)

17. earned the right through hard work(4\%)

18. others have travelled, equitable to do so too(4\%)

our big chance

worked so hard

19. inherited wealth, accept good luck(8\%)

baby boomers

silver spoon

20. thinks planet is doomed, intends to enjoy life meanwhile(2\%)

while I can

$\mathrm{N}=50$; multiple responses, percentages sum to $>100 \%$. 